\title{
Perception on Nursing Profession and Academic and Work-Related Stress Among Nursing Students in Bhutan
}

\author{
Ugyen Wangdi* and Nidup Dorji \\ Department of Public Health and Allied Sciences, Faculty of Nursing and Public Health, Bhutan
}

*Corresponding author: Ugyen Wangdi, Department of Public Health and Allied Sciences, Faculty of Nursing and Public Health, Khesar Gyalpo University of Medical Sciences of Bhutan, Bhutan

\begin{abstract}
ARTICLE INFO
Received: 幽 October 21, 2019

Published: 幽 November 01, 2019

Citation: Ugyen Wangdi, Nidup Dorji. Perception on Nursing Profession and Academic and Work-Related Stress Among Nursing Students in Bhutan. Biomed J Sci \& Tech Res 22(3)-2019. BJSTR. MS.ID.003752.
\end{abstract}

Keywords: Perception on Nursing Profession and Academic and Work-Related Stress Among Nursing Students in Bhutan

\section{ABSTRACT}

Introduction: Quality of healthcare is a concern for every government, service providers and the consumers of the healthcare services. Attitude of healthcare professionals towards their profession and the prevalence of academic and work-related stress during training greatly influence the delivery of quality health care. However, there is paucity in the scientific study to assess perceptions towards the nursing profession, academic and work-related stress among nursing students in Bhutan.

Methods: A descriptive cross-sectional survey was conducted to assess the perception of nursing students towards the nursing profession, academic and workrelated related stress. Purposive sampling method was used. Two hundred nursing students participated in the survey with a return rate of $98.04 \%$. Data were obtained through a self-administered structured questionnaire. Descriptive and bivariate analysis was performed using Statistical Package for Social Sciences (SPSS) version 21.0.

Results: The mean score for the perception towards the nursing profession was 71.59 (SD=5.37; Range: 55-84). Almost all (99\%) perceived nursing profession as an opportunity to serve humanity. Level of nursing training $(\mathrm{p}<0.001)$ and the experience of admission to hospital $(\mathrm{p}<0.05)$ influenced perception towards nursing profession. The mean academic stress was 48.29 ( $\mathrm{SD}=8.82$; Range: $22-75)$. Workload and preparation for examination (92\%) and assignments $(90.5 \%)$ contributed to high academic stress. The mean work-related stress was 19.69 (SD=4.83; Range: 7-30). Lack of professional knowledge and skills (81\%), uncertainty of patient treatment $(80 \%)$, conflict in the workplace $(79 \%)$, death and dying $(78 \%)$ added to high work-related stress. Ethnicity $(\mathrm{p}<0.05)$, parent's education level $(\mathrm{p}<0.05)$, and the experience of hospitalization $(p<0.01)$ were associated with stress.

Conclusion: Perception towards nursing profession was positive. However, nursing students confronted high level of academic and work-related stress during training. Nursing educators and clinical facilitators need to be sensitive about the prevalence of stressors and facilitate effective coping strategies.

\section{Introduction}

Quality healthcare is a concern for every government, service provider and the consumer of the health care services. High quality healthcare demand and its delivery are greatly influenced by the attitudes of healthcare professionals towards their own profession [1]. Acquiring professional values and improvement are central to professional development to enhance quality patient care and greater job satisfaction [2]. Likewise, education for the development and sustenance of professional identity and practices remain crucial [3]. An extensive body of evidence reveals factors that influence a student's view and preference for the nursing profession. Personal goals, professional values, exposure to clinical experiences, feelings of not being valued, the existence of hierarchy in the health system, perceived support from the experienced staff, experience of illnesses or hospitalization greatly influences 
view towards nursing profession[4]. Although the sense of being professional lies within the context of self and others, the sense of belonging within the nursing team was significant to the nursing student during their clinical posting [5].

A Korean study indicated nursing students' entry to the nursing profession with a higher desire for a professional job significantly had higher nursing professional values compared to those students who entered into the profession because of other reasons [5]. Studies carried out in Zambia [6], Jordan [7], Punjab [8], and Poland [9] showed positive perception towards the nursing profession and was perceived as an opportunity to serve humanity, receive blessings from people, has opportunity for personal growth and development, and achieve economic and job security. However, study findings elsewhere from China [10], Korea [5], and Turkey [11] considered nursing as a low-status profession, dependent on doctors, and participants chose the nursing profession because of financial motivation and availability of job. Nursing is consistently regarded as a predominated female profession prejudiced by the fact that nursing is feminine profession due to the idea of caring linked to the history of women [12]. There is a scarcity of male nurses almost in every country and the relationship between gender and professional values has not been consistent in the literature [5].

Perception refers to the belief, views and understanding nurses have regarding the image of the nursing profession because of their past and present experiences in the course of their training [13]. The discipline of nursing traditionally holds as the most trusted healthcare profession. For instance, in the United States, nursing was awarded as the most trusted profession for decades [14] and continues to be until date [15]. Olshansky [16] stressed that in nursing, "trust involves integrity and honesty; it involves the ability to rely on someone or something; it is fundamental to a healthy society" (p.193) [16]. At the training level, nursing students faces academic and work-related stress negatively influencing productivity [17], and the provision of quality healthcare services [18]. The consequences of stress also include poor academic outcomes and reduced cognitive ability among nursing students [19]. Stress is a non-specific response of the body to any demand and is an event or any stimulus that causes an individual to experience stress [20]. A growing body of literature from different countries indicate nursing students experience stress [21].

Assignments and workload, preparation for examination, fear of failure, uncertainty about future, lack of confidence, negative attitudes; and the fear of an unknown situations, mistakes with patients or handling technical equipment, criticism from physician and other healthcare staff were the common cited sources of stress $[17,22,23]$. Aslan et al. [24] observed a significant higher stress in nursing education among female compared to male nursing students. Compulsory university activities, work, care of a home and family are alleged to be responsible for the higher prevalence of stress among female [12,24]. Studies have revealed the experience of stress at different level of training, during transition from undergraduate to professional programs after graduation $[20,23,24]$. Nursing students displaying a greater level of stress during the second year of training is believed to be due to their first introduction to clinical environments [23]. However, according to Aslan et al. [24], the stress occurs from the first semester and continues with gradual increase reaching highest in the final year.

Failure to identify and address the perceived source of stress could lead to role confusion, decreased effort and productivity upon graduation of the nursing students [19]. Until 2014, when the first private nursing college was opened at Reldri Academic for Health Sciences (RAHS), the Faculty of Nursing and Public Health (FNPH) the then Royal Institute of Health Sciences was the sole institute to produce professional nurses in Bhutan. Ever since the training of Auxiliary Nurse Midwife (ANM) in 1975 and training of General Nurse Midwife (GNM) in 1982, a total of 1185 nurses (including Assistant Nurses, General Nurse Midwives, and Bachelor of Science Nurses) are currently working at different health centers across the country [25]. Although the perception of nursing students towards their profession and factors influencing perception is well studied both in the developed and developing countries, there is scarcity in the evidence on what influences Bhutanese nursing students' perception on their profession and the experience of academic and work-related stress. Currently, the training and the implementation of nursing processes and procedures in Bhutan have heavily relied on the existing international literature. This study aims to explore the perception of Bhutanese nursing students toward the nursing profession and enhance understanding of the presence of stress related to academic and work during their study period. Finding from this study will assist in reducing the stressors and promote the formulation of an evidence-based strategy to attract potential students pursue nursing profession in Bhutan.

\section{Methods}

This study used a descriptive analytical cross-sectional design and adopted purposive sampling technique. Data for this study was collected from 200 Bhutanese nursing students out of 204 enrolled at different levels of training from the colleges of FNPH, Thimphu and RAHS, Phuntsholing, using a self-administered questionnaire.

The questionnaire was pilot tested among 49 nursing students who recently graduated before its application in the main survey. Cronbach's alpha coefficient of 0.70 and above was considered sufficient for internal consistency [26]. Items used to assess perception towards nursing profession (Cronbach alpha $=0.70$ ) and academic and work-related stress (Cronbach alpha $=0.93$ ) achieved sufficient internal consistency score. The finalized questionnaire was administered during one of the ongoing classes, and the investigator checked for the completeness. Before the distribution of the questionnaire, participants were briefed on the aims and the objectives of the study, information to obtain consent, right to non-participation, and maintenance of confidentiality. After 
the completion of data collection, data was entered into Epi Data version 3.1 .

Once the data entry and data cleansing were completed, the data was transferred to Statistical Package for Social Sciences (SPSS) version 21.0 for analysis. Both descriptive and inferential statistical test were applied. For the descriptive statistics, count and percentage, mean and standard deviation, maximum and minimum were calculated to describe the data. Concerning the inferential statistics, chi-square, independent t-test, and oneway ANOVA were used to determine the relationships between the variables. For the ANOVA test, post hoc test with Tukey was applied to confirm the difference between the groups. Ethics approval was obtained from the Research Ethics Board of Health (REBH) through letter No. REBH/PO/2018/059 with further administrative clearance from the Ministry of Health vide clearance No.: PPD/ADM.CL/9.2018/646 and respective institutes before the commencement of data collection.

\section{Results}

\section{The Socio-Demographic Characteristics}

The socio-demographic characteristics of this study are presented in Table 1. The study participants consisted of $65 \%(n=130)$ females and $35 \%(n=70)$ males with a majority $(97 \%)$ ranged between 18 to 24 years. About $79 \%$ of the participants were Buddhist followed by Hindu and Christianity. Slightly more than one third (36\%) of the participants were in level three of their nursing training. Nearly half (46\%) and about three quarters (72\%) revealed their father and mother with no formal education background. More than half (58\%) of the participant's father and 89\% of their mother were farmer. Most participants (90\%) reported none of their family members present in the nursing profession. However, their father (24.5\%) and mother (15.5\%) did influence participants to take up nursing as their profession. While $13 \%$ of the participants reported having suffered from chronic health conditions, $30.1 \%$ had the experience of admitted to the healthcare centre. More than half (51\%) reported having stayed in the hospital attending their patient(s).

Table 1: Distribution of the socio-demographic characteristics of the study participants.

\begin{tabular}{|c|c|}
\hline Socio-demographic variables & $n(\%)$ \\
\hline \multicolumn{2}{|l|}{ Level of nursing training } \\
\hline First year & $66(33.0)$ \\
\hline Second year & $62(31.0)$ \\
\hline Third year & $72(36.0)$ \\
\hline \multicolumn{2}{|l|}{ Age (in years) } \\
\hline$<18$ & $3(1.5)$ \\
\hline $18-24$ & $194(97.0)$ \\
\hline$\geq 25$ & $3(1.5)$ \\
\hline \multicolumn{2}{|l|}{ Sex } \\
\hline Male & $70(35.0)$ \\
\hline Female & $130(65.0)$ \\
\hline \multirow{2}{*}{$\begin{array}{l}\text { Religion } \\
\text { Buddhist }\end{array}$} & \\
\hline & \\
\hline Hindu & $34(1 / .0)$ \\
\hline Christian & $7(3.5)$ \\
\hline & $1(0.5)$ \\
\hline \multicolumn{2}{|l|}{ Ethnicity } \\
\hline Tshangla & $73(36.5)$ \\
\hline Ngalop & $35(17.5)$ \\
\hline Kheng-Bumthab & $18(9.0)$ \\
\hline Lhotshampa & $53(26.5)$ \\
\hline Others & $21(10.5)$ \\
\hline
\end{tabular}




\begin{tabular}{|c|c|}
\hline \multicolumn{2}{|l|}{ Education of father } \\
\hline No education & $92(46.0)$ \\
\hline Primary & $56(28.0)$ \\
\hline High school & $11(5.5)$ \\
\hline University & $11(5.5)$ \\
\hline Diploma/certificate & $16(8.0)$ \\
\hline Monastic education & $9(4.5)$ \\
\hline Non-formal education & $5(2.5)$ \\
\hline Others & $0(0.5)$ \\
\hline \multicolumn{2}{|l|}{ Education of mother } \\
\hline No education & $144(72.0)$ \\
\hline Primary & $26(13.0)$ \\
\hline High school & $9(4.5)$ \\
\hline University & $1(0.5)$ \\
\hline Diploma/certificate & $0(0.0)$ \\
\hline Monastic education & $0(0.0)$ \\
\hline Non-formal education & $18(9.0)$ \\
\hline Others & $2(1.0)$ \\
\hline \multicolumn{2}{|l|}{ Occupation of father } \\
\hline Farmer & $116(58.0)$ \\
\hline Contractor & $4(2.0)$ \\
\hline Private employee & $22(11.0)$ \\
\hline Govt. servant & $44(22.0)$ \\
\hline Others & $14(7.0)$ \\
\hline Occupation of mother & \multirow{2}{*}{$178(89.0)$} \\
\hline Farmer & \\
\hline \multirow{2}{*}{$\begin{array}{c}\text { Contractor } \\
\text { Private employee }\end{array}$} & $0(0.0)$ \\
\hline & $7(3.5)$ \\
\hline Govt. servant & $0(4.0)$ \\
\hline Others & $7(3.5)$ \\
\hline Family members in nursing & \multirow{2}{*}{$20(10.0)$} \\
\hline Yes & \\
\hline No & $180(90.0)$ \\
\hline on to take up nursing course & \multirow{2}{*}{$49(24.5)$} \\
\hline Father & \\
\hline Mother & $31(15.5)$ \\
\hline Uncle & $13(6.5)$ \\
\hline Aunty & $7(3.5)$ \\
\hline $\begin{array}{l}\text { Aunty } \\
\text { Brother }\end{array}$ & \multirow{2}{*}{$\begin{array}{l}19(9.5) \\
17(8.5)\end{array}$} \\
\hline Sister & \\
\hline Others & $64(32.0)$ \\
\hline Have you ever suffered from chronic health condition & \multirow{2}{*}{$26(13.0)$} \\
\hline Yes & \\
\hline No & $174(87.0)$ \\
\hline
\end{tabular}




\begin{tabular}{|c|c|}
\hline Have you ever been admitted to hospital $(\mathrm{n}=133)$ & $40(30.1)$ \\
Yes & $93(69.9)$ \\
No & \\
\hline $\begin{array}{c}\text { Have anyone of your family members suffered from chronic health } \\
\text { conditions }\end{array}$ & $100(50.0)$ \\
Yes & $100(50.0)$ \\
No & $102(51.0)$ \\
\hline Have you ever stayed in the hospital as patient attendant & $98(49.0)$ \\
\hline
\end{tabular}

\section{Perception towards Nursing Profession}

As shown in Table 2, the average score for the feeling and perception towards the nursing profession in this study stand at 71.59 (SD: 5.37) in a score range of 55 - 84. Almost all (99\%) the participants agreed or strongly agreed the nursing profession is an opportunity to serve humanity. Ninety-two percent agreed nursing is a caring profession, which offers an opportunity for personal growth and development and is a means to earn merits and virtues (93\%). Nearly three-quarters (76.5\%) agreed to strongly agreed the nursing profession as a dignified and respectful profession. Although more than half (52\%) agreed that the nursing profession has equal recognition with other categories of healthcare professionals, $26.5 \%$ were not sure about it. About a quarter (22.5\%) of the participants were unsure if nursing is similar to a cleaner's job. Approximately $78 \%$ of the participants agreed or strongly agreed the nursing profession is to assist medical doctors, and 68\% perceive nursing is not an independent profession. However, about $76.5 \%$ reported having no regret joining the nursing profession. Most (85.5\%) agreed the nursing profession is a tiring and risky job. Although $60 \%$ disagreed or strongly disagreed nursing is a women's job, $31 \%$ still agreed or strongly agreed nursing is a women's profession. After joining into the nursing course, a majority (73.5\%) disagreed that they developed a negative image for the nursing profession. About $72.0 \%$ of the participants believed nurses have good career advancement, while $23.5 \%$ are not sure.

Table 2: Feelings and perception towards nursing profession among the participants $(n=200)$.

\begin{tabular}{|c|c|c|c|c|c|c|}
\hline \multirow{2}{*}{ S/No. } & \multirow{2}{*}{ Perceptions towards nursing profession. } & Strongly agree & Agree & Not sure & Disagree & Strongly disagree \\
\hline & & n(\%) & n(\%) & $\mathrm{n}(\%)$ & n(\%) & n(\%) \\
\hline \multicolumn{7}{|c|}{ Nursing (profession) is/has: } \\
\hline 1 & An opportunity to serve humanity & $182(91.0)$ & $16(8.0)$ & $0(0.0)$ & $0(0.0)$ & $2(1.0)$ \\
\hline 2 & An opportunity for personal growth & $85(42.5)$ & $99(49.5)$ & $12(6.0)$ & $4(2.0)$ & $0(0.0)$ \\
\hline 3 & A Caring profession & $85(42.5)$ & $99(49.5)$ & $12(6.0)$ & $4(2.0)$ & $0(0.0)$ \\
\hline 4 & A way to get recognition in the society & $24(12.0)$ & $87(43.5)$ & $63(31.5)$ & $19(9.5)$ & $7(3.5)$ \\
\hline 5 & A dignified and respectful profession & $70(35.0)$ & $83(41.5)$ & $35(17.5)$ & $10(5.0)$ & $2(1.0)$ \\
\hline 6 & A means to earn merit & $127(63.5)$ & $59(29.5)$ & $13(6.5)$ & $1(0.5)$ & $0(0.0)$ \\
\hline 7 & $\begin{array}{l}\text { Equal recognition with other health care } \\
\text { professions }\end{array}$ & $19(9.5)$ & $85(42.5)$ & $53(26.5)$ & $33(16.5)$ & $10(5.0)$ \\
\hline 8 & Women's profession & $20(10.0)$ & $42(21.0)$ & $18(9.0)$ & $82(41.0)$ & $38(19.0)$ \\
\hline 9 & Similar to a cleaner's job & $9(4.5)$ & $30(15.0)$ & $45(22.5)$ & $78(39.0)$ & $38(19.0)$ \\
\hline 10 & To assists medical doctors & $46(23.0)$ & $110(55.0)$ & $17(8.5)$ & $22(11.0)$ & $5(2.5)$ \\
\hline 11 & $\begin{array}{l}\text { No appreciation from people including } \\
\text { patients/clients }\end{array}$ & $9(4.5)$ & $60(39.0)$ & $66(33.0)$ & $54(27.0)$ & $11(5.5)$ \\
\hline 12 & $\begin{array}{l}\text { Not an independent profession because nurses } \\
\text { don't make their own decision }\end{array}$ & $47(23.5)$ & $89(44.5)$ & $30(10.5)$ & $21(10.5)$ & $13(6.5)$ \\
\hline 13 & Not an important profession in patient care & $5(2.5)$ & $4(2.0)$ & $7(3.5)$ & $79(39.5)$ & $105(52.5)$ \\
\hline 14 & $\begin{array}{l}\text { One of the profession I will not encourage my } \\
\text { children to join it }\end{array}$ & $15(7.5)$ & $22(11.0)$ & $42(21.0)$ & $60(30.0)$ & $61(30.5)$ \\
\hline 15 & Profession I regret having joined it & $5(2.5)$ & $14(7.0)$ & $28(14.0)$ & $81(40.5)$ & $72(36.0)$ \\
\hline 16 & Profession I am satisfied and happy about it & $60(30.0)$ & $90(45.0)$ & $34(17.0)$ & $11(5.5)$ & $5(2.5)$ \\
\hline
\end{tabular}




\begin{tabular}{|c|c|c|c|c|c|c|}
\hline 17 & A tiring and a risky job & $78(39.0)$ & $93(46.5)$ & $10(5.0)$ & $16(8.0)$ & $3(1.5)$ \\
\hline 18 & $\begin{array}{c}\text { After joining into nursing course, I had negative } \\
\text { image for nursing profession }\end{array}$ & $4(2.0)$ & $27(13.5)$ & $22(11.0)$ & $89(44.5)$ & $58(29.0)$ \\
\hline 19 & Has a good career ladder/advancement & $52(26.0)$ & $92(46.0)$ & $47(23.5)$ & $8(4.0)$ & $1(0.5)$ \\
\hline & Total perception score (n=200) & \multicolumn{3}{|c|}{ Mean \pm Standard Deviation: $71.59 \pm 5.37 ;$ Min-max: $55-84$} \\
\hline
\end{tabular}

\section{Academic Stress}

The average academic stress score for this study stands at 48.29 (SD: 8.82) in a score range of 22-74. Most participants $(92.0 \%)$ perceived course workload stressful as is the course exam preparation. Theoretical level of the contents (54.5\%), meeting academic demands (56.5\%), attending assignments and workload $(61.5 \%)$ were perceived stressful to severely stressful. Similarly, meeting the own standards of achievement was also perceived as moderate to severely stressful (80\%). Academic writing requirements of the course, teaching methodologies, and lectures lasting more than an hour were also perceived moderate to severely stressful at $80.5 \%, 69 \%$, and $77.5 \%$, respectively. Class attendance (68\%) and maintenance of a relationship with the lecturers (64.5\%) were perceived little to no stress (Table 3).

Table 3: Academic stress among the participants $(n=200)$.

\begin{tabular}{|c|c|c|c|c|c|c|}
\hline \multirow{2}{*}{ S/No. } & \multirow{2}{*}{ Potential Stressors } & Severe stress & Stressful & Moderate stress & A little stress & Never stress \\
\hline & & $n(\%)$ & $n(\%)$ & n(\%) & $n(\%)$ & $n(\%)$ \\
\hline \multicolumn{7}{|c|}{ Stress related to academic includes: } \\
\hline 1 & The course workload & $19(9.5)$ & $118(59.0)$ & $47(23.5)$ & $15(7.5)$ & $1(0.5)$ \\
\hline 2 & $\begin{array}{c}\text { The demand of writing assignment to the expected } \\
\text { standard }\end{array}$ & $14(7.0)$ & $11(38.5)$ & $81(40.5)$ & $27(13.5)$ & $1(0.5)$ \\
\hline 3 & Preparing for the course examination & $49(24.5)$ & $97(48.5)$ & $38(19.0)$ & $14(7.0)$ & $2(1.0)$ \\
\hline 4 & Meeting personal need while studying & $16(8.0)$ & $55(27.5)$ & $77(38.5)$ & $39(19.5)$ & $13(6.5)$ \\
\hline 5 & Meeting the academic demands of the program & $28(14.0)$ & $85(42.5)$ & $59(29.5)$ & $20(10.0)$ & $8(4.0)$ \\
\hline 6 & The theoretical level of content of the course & $24(12.0)$ & $85(42.5)$ & $68(34.0)$ & $18(9.0)$ & $5(2.5)$ \\
\hline 7 & My own standards of achievement & $21(10.5)$ & $54(27.0)$ & $85(42.5)$ & $35(17.5)$ & $5(2.5)$ \\
\hline 8 & Personal time management & $19(9.5)$ & $57(28.5)$ & $66(33.0)$ & $49(24.5)$ & $9(4.5)$ \\
\hline 9 & Academic writing required on the course & $16(8.0)$ & $73(36.5)$ & $72(36.0)$ & $32(16.0)$ & $7(3.5)$ \\
\hline 10 & Assignment and workload & $36(18.0)$ & $87(43.5)$ & $58(29.0)$ & $17(8.5)$ & $2(1.0)$ \\
\hline 11 & Perceived pressure to keep up with other students & $12(6.0)$ & $55(27.5)$ & $72(36.0)$ & $40(20.0)$ & $21(10.5)$ \\
\hline 12 & The teaching methodologies & $14(7.0)$ & $46(23.0)$ & $78(39.0)$ & $49(24.5)$ & $13(6.5)$ \\
\hline 13 & Lectures lasting more than one hour & $37(18.5)$ & $68(34.0)$ & $50(25.0)$ & $33(16.5)$ & $12(6.0)$ \\
\hline 14 & Attendance at classes & $8(4.0)$ & $20(10.0)$ & $36(18.0)$ & $40(20.0)$ & 96(48.0) \\
\hline \multirow[t]{2}{*}{15} & Relationship with lecturer & $21(10.5)$ & $22(11.0)$ & $28(14.0)$ & $66(33.0)$ & $63(31.5)$ \\
\hline & Total academic stress score & \multicolumn{5}{|c|}{ Mean \pm Standard Deviation: $48.29 \pm 8.82 ;$ Min-max: $22-75$} \\
\hline
\end{tabular}

\section{Work-Related Stress}

As shown in (Table 4), the average work-related stress was 19.69 (SD: 4.83) in a score range of 7-30. Events such as death and dying (77\%), uncertainty on patient treatment (80.5\%), conflict
(79\%) and lack of professional knowledge and skills (81\%) were perceived moderate to severely stressful. A little less than half perceived little to no stress in taking care of patients (41\%), and exposure to clinical environments (34.5\%).

Table 4: Work-related stress among the participants $(n=200)$.

\begin{tabular}{|c|c|c|c|c|c|c|}
\hline \multirow{2}{*}{ S/No. } & Work related stress items & Severe stress & Stressful & Moderate stress & A little stress & Never stress \\
\cline { 3 - 6 } & & $\mathbf{n ( \% )}$ & $\mathbf{n ( \% )}$ & $\mathbf{n ( \% )}$ & $\mathbf{n ( \% )}$ & $\mathbf{n ( \% )}$ \\
\hline 1 & Stress with death and dying of patient & $51(25.5)$ & $67(33.5)$ & $36(18.0)$ & $31(15.5)$ & $15(7.5)$ \\
\hline 2 & Stress from uncertainty regarding patient treatment & $30(15.0)$ & $82(41.0)$ & $49(24.5)$ & $31(15.5)$ & $8(4.0)$ \\
\hline 3 & Stress from conflict & $25(12.5)$ & $81(40.5)$ & $52(26.0)$ & $34(17.0)$ & $8(4.0)$ \\
\hline 4 & Stress from lack of professional knowledge and skills & $40(20.0)$ & $67(33.5)$ & $55(27.5)$ & $32(16.0)$ & $6(3.0)$ \\
\hline
\end{tabular}




\begin{tabular}{|c|c|c|c|c|c|c|}
\hline 5 & Stress from taking care of patients & $6(3.0)$ & $41(20.5)$ & $71(35.5)$ & $56(28.0)$ & $26(13.0)$ \\
\hline 6 & Stress from clinical environment & $15(7.5)$ & $65(32.5)$ & $51(25.5)$ & $48(24.0)$ & $21(10.5)$ \\
\hline & Total work-related stress score & \multicolumn{5}{|c|}{ Mean \pm Standard Deviation: 19.69 $\pm 4.83 ;$ Min-max: $7-30$} \\
\hline
\end{tabular}

Relationship Between Socio-Demographic Characteris- sion. As illustrated in (Table 5), perception towards the nursing tics and Perception Towards Nursing Profession Among profession was significantly related to the level of nursing training the Study Participants

A relationship was tested between socio-demographic characteristics, perception, and feelings towards the nursing profes$(\mathrm{p}<0.001)$. Better perception towards the nursing profession was found among the first-year nursing students $(M=74.15 \pm 4.08)$ compared to the higher level of nursing training.

Table 5: Bivariate relationship between socio-demographic characteristics and perception towards nursing profession among the study participants.

\begin{tabular}{|c|c|c|c|}
\hline \multirow{2}{*}{ Socio-demographic variables } & \multirow{2}{*}{ Total } & Perception towards nursing profession & \multirow{2}{*}{ p-value } \\
\hline & & $\mathrm{M} \pm \mathrm{SD}$ & \\
\hline $\begin{array}{l}\text { Level of nursing training } \\
\text { First year } \\
\text { Second year } \\
\text { Third year }\end{array}$ & $\begin{array}{l}66 \\
62 \\
72\end{array}$ & $\begin{array}{l}74.15 \pm 4.08 \\
69.37 \pm 5.36 \\
71.15 \pm 5.49\end{array}$ & $0.000^{* * *}$ \\
\hline $\begin{array}{c}\text { Age (in years) } \\
<18 \\
18-24 \\
\geq 25\end{array}$ & $\begin{array}{c}3 \\
194 \\
3\end{array}$ & $\begin{array}{l}68.67 \pm 7.64 \\
71.57 \pm 5.29 \\
75.67 \pm 8.39\end{array}$ & 0.673 \\
\hline $\begin{array}{c}\text { Sex } \\
\text { Male } \\
\text { Female }\end{array}$ & $\begin{array}{c}70 \\
130\end{array}$ & $\begin{array}{l}71.70 \pm 6.11 \\
71.53 \pm 4.95\end{array}$ & 0.832 \\
\hline $\begin{array}{c}\text { Religion } \\
\text { Buddhist } \\
\text { Non-Buddhist }\end{array}$ & $\begin{array}{c}158 \\
42\end{array}$ & $\begin{array}{l}71.75 \pm 5.32 \\
71.00 \pm 5.55\end{array}$ & 0.424 \\
\hline $\begin{array}{c}\text { Ethnicity } \\
\text { Tshangla } \\
\text { Ngalop } \\
\text { Kheng-Bumthab } \\
\text { Lhotshampa } \\
\text { Others }\end{array}$ & $\begin{array}{l}73 \\
35 \\
18 \\
53 \\
21\end{array}$ & $\begin{array}{l}71.75 \pm 5.01 \\
70.63 \pm 5.77 \\
71.00 \pm 6.33 \\
72.00 \pm 5.37 \\
72.10 \pm 5.28\end{array}$ & 0.757 \\
\hline $\begin{array}{l}\text { Education of the father } \\
\text { No formal education } \\
\text { Some form of formal education }\end{array}$ & $\begin{array}{c}92 \\
108\end{array}$ & $\begin{array}{l}71.10 \pm 5.48 \\
72.01 \pm 5.26\end{array}$ & 0.232 \\
\hline $\begin{array}{c}\text { Education of the mother } \\
\text { No formal education } \\
\text { Some form of formal education }\end{array}$ & $\begin{array}{c}144 \\
56\end{array}$ & $\begin{array}{l}71.51 \pm 5.56 \\
71.80 \pm 4.86\end{array}$ & 0.711 \\
\hline $\begin{array}{l}\text { Occupation of father } \\
\text { Farmer } \\
\text { Other occupation }\end{array}$ & $\begin{array}{c}116 \\
84\end{array}$ & $\begin{array}{l}71.09 \pm 5.49 \\
72.29 \pm 5.13\end{array}$ & 0.119 \\
\hline $\begin{array}{l}\text { Occupation of mother } \\
\text { Farmer } \\
\text { Other occupation }\end{array}$ & $\begin{array}{c}178 \\
22\end{array}$ & $\begin{array}{l}71.43 \pm 5.22 \\
72.91 \pm 6.44\end{array}$ & 0.223 \\
\hline
\end{tabular}




\begin{tabular}{|c|c|c|c|}
\hline $\begin{array}{l}\text { Family members in nursing } \\
\qquad \begin{array}{c}\text { Yes } \\
\text { No }\end{array}\end{array}$ & $\begin{array}{c}20 \\
180\end{array}$ & $\begin{array}{l}71.30 \pm 5.35 \\
71.62 \pm 5.38\end{array}$ & 0.379 \\
\hline $\begin{array}{c}\text { Most influential person } \\
\text { Parents } \\
\text { Others }\end{array}$ & $\begin{array}{r}80 \\
120\end{array}$ & $\begin{array}{l}72.46 \pm 4.68 \\
71.01 \pm 5.72\end{array}$ & 0.051 \\
\hline $\begin{array}{l}\text { Have you ever suffered from chronic health } \\
\text { condition } \\
\text { Yes } \\
\text { No }\end{array}$ & $\begin{array}{c}26 \\
174\end{array}$ & $\begin{array}{l}72.08 \pm 6.67 \\
71.52 \pm 5.16\end{array}$ & 0.621 \\
\hline $\begin{array}{l}\text { Have you ever been admitted to hospital } \\
\qquad \begin{array}{c}(\mathrm{n}=133) \\
\text { Yes } \\
\text { No }\end{array}\end{array}$ & $\begin{array}{l}40 \\
93\end{array}$ & $\begin{array}{r}72.65 \pm 6.03 \\
70.53 \pm 5.19\end{array}$ & $0.041^{*}$ \\
\hline $\begin{array}{l}\text { Have anyone of your family members suffered } \\
\text { from chronic health conditions } \\
\qquad \begin{array}{l}\text { Yes } \\
\text { No }\end{array}\end{array}$ & $\begin{array}{l}100 \\
100\end{array}$ & $\begin{array}{l}72.05 \pm 4.88 \\
71.13 \pm 5.80\end{array}$ & 0.226 \\
\hline $\begin{array}{l}\text { Have you ever stayed in the hospital as patient } \\
\text { attendant } \\
\qquad \begin{array}{l}\text { Yes } \\
\text { No }\end{array}\end{array}$ & $\begin{array}{c}102 \\
98\end{array}$ & $\begin{array}{l}71.72 \pm 5.24 \\
71.46 \pm 5.52\end{array}$ & 0.736 \\
\hline
\end{tabular}

Although the relationship between the levels of education for both the parents and the perception towards the nursing profession was not significant, there is a trend parent's influence choice for the nursing profession. The experience of having admitted to hospitals was significantly related to better perception $(M=72.65 \pm 6.03)$ for the nursing profession $(\mathrm{p}<0.05)$.

\section{Bivariate Relationship Between Socio-Demographic Characteristics, Academic and Work-Related Stress}

Total stress including the academic and work-related stress was tested for the relationship with the socio-demographic characteristics of the participants. While the total and academic stress was not, the age of the participants was significantly related to work-related stress $(\mathrm{p}<0.05)$. Tukey HSD Post hoc test revealed those in the age range of 18-24 years recorded a higher mean score for work-related stress $(M=19.68, S D=5.07)$ compared to the older participants. The relationship between total and academic-related stress and ethnicity was also significant $(\mathrm{p}<0.05)$. Participants with Ngalop background reported higher total and academic stress score. Both the parents with some form of the educational background was also significantly linked to higher total and academic stress mean score $(p<0.01)$. Although the relationship between the occupation of the mother was not significant with stress, higher academic stress $(M=49.79$; $S D=8.47)$ was recorded for father coming with non-farming background $(\mathrm{p}<0.05)$. Concerning the experience of participants admitted to the hospital, a significant relationship was shown with total $(\mathrm{p}<0.05)$, academic $(\mathrm{p}<0.05)$, and work-related stress $(\mathrm{p}<0.05)$. Participants who had no experience of admission to the hospitals recorded higher total, academic and work-related stress compared to those who had the experience of admission to the hospitals (Table 6).

Table 6: Bivariate relationship between socio-demographic characteristics, academic and work-related stress.

\begin{tabular}{|c|c|c|c|c|c|c|c|}
\hline Socio-demographic variables & Total & $\begin{array}{c}\text { Total Stress } \\
\text { M } \pm \text { SD }\end{array}$ & $p$-value & $\underset{\mathrm{M} \pm \mathrm{SD}}{\mathrm{AS}}$ & $p$-value & $\begin{array}{c}\text { WS } \\
\mathrm{M} \pm \mathrm{SD}\end{array}$ & $p$-value \\
\hline $\begin{array}{l}\text { Levels of nursing training } \\
\qquad \begin{array}{c}\text { First year } \\
\text { Second year } \\
\text { Third year }\end{array}\end{array}$ & $\begin{array}{l}66 \\
62 \\
72\end{array}$ & $\begin{array}{l}68.63 \pm 10.19 \\
69.81 \pm 12.26 \\
65.88 \pm 11.54\end{array}$ & 0.129 & $\begin{array}{l}47.80 \pm 7.92 \\
50.13 \pm 9.21 \\
47.14 \pm 9.14\end{array}$ & 0.127 & $\begin{array}{l}20.73 \pm 4.41 \\
19.68 \pm 5.07 \\
18.74 \pm 4.87\end{array}$ & 0.053 \\
\hline $\begin{array}{c}\text { Age (in years) } \\
<18 \\
18-24^{\mathrm{a}} \\
\geq 25^{\mathrm{b}}\end{array}$ & $\begin{array}{c}3 \\
194 \\
3\end{array}$ & $\begin{array}{l}71.67 \pm 12.50 \\
67.94 \pm 11.58 \\
66.33 \pm 11.59\end{array}$ & 0.833 & $\begin{array}{l}51.67 \pm 9.50 \\
48.13 \pm 8.83 \\
54.67 \pm 7.77\end{array}$ & 0.358 & $\begin{array}{c}20.00 \pm 3.00 \\
19.80 \pm 4.78 \mathrm{~b} \\
11.67 \pm 4.16 \mathrm{a}\end{array}$ & $0.014^{*}$ \\
\hline
\end{tabular}




\begin{tabular}{|c|c|c|c|c|c|c|c|}
\hline $\begin{array}{l}\text { Sex } \\
\text { Male } \\
\text { Female }\end{array}$ & $\begin{array}{c}70 \\
130\end{array}$ & $\begin{array}{l}65.74 \pm 14.01 \\
69.17 \pm 69.17\end{array}$ & 0.072 & $\begin{array}{c}46.77 \pm 10.11 \\
49.10 \pm 7.97\end{array}$ & 0.075 & $\begin{array}{c}18.97 \pm 5.49 \\
20.07 \pm 4.41\end{array}$ & 0.152 \\
\hline $\begin{array}{l}\text { Religion } \\
\text { Buddhist } \\
\text { Others }\end{array}$ & $\begin{array}{c}158 \\
42\end{array}$ & $\begin{array}{l}48.33 \pm 11.86 \\
67.12 \pm 10.34\end{array}$ & 0.592 & $\begin{array}{l}48.33 \pm 9.06 \\
48.12 \pm 7.96\end{array}$ & 0.891 & $\begin{array}{l}19.87 \pm 4.94 \\
19.00 \pm 4.40\end{array}$ & 0.303 \\
\hline $\begin{array}{c}\text { Ethnicity } \\
{ }^{a} \text { Tshangla } \\
\text { bNgalop } \\
\text { 'Kheng-dBumthab } \\
\text { éLhotshampa } \\
\text { fOthers }\end{array}$ & $\begin{array}{l}73 \\
35 \\
18 \\
53 \\
21\end{array}$ & $\begin{array}{c}67.73 \pm 11.21 \\
73.03 \pm 10.71 \mathrm{e} \\
66.50 \pm 8.83 \\
67.19 \pm 12.19 \\
63.62 \pm 12.49 \mathrm{~b}\end{array}$ & $0.034^{*}$ & $\begin{array}{c}47.18 \pm 8.36 \mathrm{be} \\
52.26 \pm 9.52 \mathrm{ae} \\
48.11 \pm 6.90 \\
48.55 \pm 9.04 \\
45.00 \pm 8.52 \mathrm{ab}\end{array}$ & $0.023^{*}$ & $\begin{array}{r}20.55 \pm 5.02 \\
20.77 \pm 3.93 \\
18.39 \pm 4.22 \\
18.64 \pm 4.82 \\
18.62 \pm 5.44\end{array}$ & 0.063 \\
\hline $\begin{array}{c}\text { Education of father } \\
\text { No formal education } \\
\text { Some form of formal education }\end{array}$ & $\begin{array}{c}92 \\
108\end{array}$ & $\begin{array}{l}66.13 \pm 11.94 \\
69.54 \pm 10.10\end{array}$ & $0.037^{*}$ & $\begin{array}{l}46.80 \pm 8.75 \\
49.55 \pm 8.73\end{array}$ & $0.028^{*}$ & $\begin{array}{l}19.33 \pm 4.94 \\
19.99 \pm 4.74\end{array}$ & 0.334 \\
\hline $\begin{array}{c}\text { Education of mother } \\
\text { No formal education } \\
\text { Some form of formal education }\end{array}$ & $\begin{array}{c}144 \\
56\end{array}$ & $\begin{array}{c}66.58 \pm 12.11 \\
71.54 \pm 9.07\end{array}$ & $0.006^{* *}$ & $\begin{array}{l}47.24 \pm 9.13 \\
50.98 \pm 7.41\end{array}$ & $0.007^{* *}$ & $\begin{array}{c}19.35 \pm 4.92 \\
20.55 \pm 4.54\end{array}$ & 0.113 \\
\hline $\begin{array}{l}\text { Occupation of father } \\
\qquad \text { Farmer } \\
\text { Other than farmer }\end{array}$ & $\begin{array}{c}116 \\
84\end{array}$ & $\begin{array}{l}66.67 \pm 11.93 \\
69.76 \pm 10.79\end{array}$ & 0.057 & $\begin{array}{l}47.20 \pm 8.95 \\
49.79 \pm 8.47\end{array}$ & $0.039 *$ & $\begin{array}{c}19.47 \pm 4.86 \\
19.98 \pm 4.81\end{array}$ & 0.469 \\
\hline $\begin{array}{l}\text { Occupation of mother } \\
\qquad \text { Farmer } \\
\text { Other than farmer }\end{array}$ & $\begin{array}{c}178 \\
22\end{array}$ & $\begin{array}{l}67.93 \pm 11.36 \\
68.27 \pm 13.21\end{array}$ & 0.897 & $\begin{array}{l}48.12 \pm 8.72 \\
49.59 \pm 9.73\end{array}$ & 0.463 & $\begin{array}{c}19.81 \pm 4.81 \\
18.68 \pm 5.05\end{array}$ & 0.303 \\
\hline $\begin{array}{l}\text { Family members in nursing } \\
\qquad \begin{array}{l}\text { Yes } \\
\text { No }\end{array}\end{array}$ & $\begin{array}{c}20 \\
180\end{array}$ & $\begin{array}{l}68.35 \pm 10.20 \\
67.93 \pm 11.70\end{array}$ & 0.877 & $\begin{array}{l}48.55 \pm 8.30 \\
48.26 \pm 8.90\end{array}$ & 0.888 & $\begin{array}{c}19.80 \pm 4.80 \\
19.67 \pm 4.85\end{array}$ & 0.911 \\
\hline $\begin{array}{l}\text { Most influential person to take up nursing } \\
\text { course } \\
\text { Parents } \\
\text { others }\end{array}$ & $\begin{array}{c}80 \\
120\end{array}$ & $\begin{array}{l}67.40 \pm 12.34 \\
68.35 \pm 11.01\end{array}$ & 0.57 & $\begin{array}{l}47.76 \pm 9.63 \\
48.63 \pm 8.26\end{array}$ & 0.496 & $\begin{array}{c}19.64 \pm 4.92 \\
19.72 \pm 4.90\end{array}$ & 0.91 \\
\hline $\begin{array}{l}\text { Have you ever suffered from chronic health } \\
\text { condition } \\
\qquad \begin{array}{l}\text { Yes } \\
\text { No }\end{array}\end{array}$ & $\begin{array}{r}26 \\
174\end{array}$ & $\begin{array}{l}68.54 \pm 11.87 \\
67.89 \pm 11.52\end{array}$ & 0.788 & $\begin{array}{c}49.46 \pm 10.07 \\
48.11 \pm 8.64\end{array}$ & 0.467 & $\begin{array}{r}19.08 \pm 5.34 \\
19.78 \pm 4.76\end{array}$ & 0.493 \\
\hline $\begin{array}{l}\text { Have you ever been admitted to hospital } \\
\qquad \begin{array}{c}(n=133) \\
\text { Yes } \\
\text { No }\end{array}\end{array}$ & $\begin{array}{l}40 \\
93\end{array}$ & $\begin{array}{l}64.35 \pm 12.40 \\
70.20 \pm 10.52\end{array}$ & $0.006^{* *}$ & $\begin{array}{l}46.20 \pm 9.27 \\
49.81 \pm 8.48\end{array}$ & $0.031^{*}$ & $\begin{array}{l}18.15 \pm 5.48 \\
20.40 \pm 4.33\end{array}$ & $0.025^{*}$ \\
\hline $\begin{array}{l}\text { Have anyone of your family members } \\
\text { suffered from chronic health conditions } \\
\text { Yes } \\
\text { No }\end{array}$ & $\begin{array}{l}100 \\
100\end{array}$ & $\begin{array}{l}67.93 \pm 11.08 \\
68.01 \pm 12.04\end{array}$ & 0.961 & $\begin{array}{l}47.89 \pm 8.44 \\
48.68 \pm 9.21\end{array}$ & 0.528 & $\begin{array}{c}20.04 \pm 4.84 \\
19.33 \pm 4.83\end{array}$ & 0.3 \\
\hline $\begin{array}{l}\text { Have you ever stayed in the hospital as } \\
\text { patient attendant } \\
\text { Yes } \\
\text { No }\end{array}$ & $\begin{array}{c}102 \\
98\end{array}$ & $\begin{array}{l}68.95 \pm 11.43 \\
66.95 \pm 11.62\end{array}$ & 0.221 & $\begin{array}{l}48.93 \pm 8.52 \\
47.61 \pm 9.13\end{array}$ & 0.292 & $\begin{array}{l}20.02 \pm 4.97 \\
19.34 \pm 4.69\end{array}$ & 0.319 \\
\hline
\end{tabular}




\section{Discussion}

This study assessed the perception of pre-service nursing students towards the nursing profession. The study sample consisted mostly of females and their enrolment in the nursing course maybe attributed to the fact that nursing was historically a female-dominated profession internationally. The government of Bhutan has also given more preference to females compared to males while recruiting in the nursing course annually [27]. The majority of the female gender enrolling in nursing profession are evident from other studies in Zambia [6], Nigeria [13], and India [28]. Historically women have been the caregiver of the sick family members and the perception of nursing as a gender-segregated profession meant for females emerged when Florence Nightingale established nursing as a women's job [13]. In this study, the level of nursing training and perception towards the nursing profession was significant. First year nursing students showed a higher perception score towards the nursing profession compared to the second- and third-year students. This finding is in contrast with the Korean study, where the score for perception towards the nursing profession was higher among the senior nurses [5].

Bang et al. [5] supported that the better perception maybe due to a change in the perception of nursing service roles after the clinical posting. Agreeing with the findings from other studies [7-9], almost all the participants in this study perceived the nursing profession as a dignified and respectful profession and has an opportunity to serve humanity and earn merits and virtues. Participants in this study perceived nursing profession has equal recognition with other healthcare professions. Therefore, nursing students may have chosen nursing course due to job security and easy entry into the nursing course as reported consistently in the Turkish [11] and Indian studies [28]. In the current study, the father's educational background had a significant influence on the better perception towards the nursing profession and the choice as their career. Similar findings were reported in a Turkish study [11], where family and friends were indicated as the powerful motivators and encouragement from father was considered imperative. Likewise, family member encouraged and supported young students apply for the nursing courses to fulfill parent's dream [7].

Similarly, in the Bhutanese context, parents often want their children to join in nursing profession in order to get a secure job and help family members at the time of illness. In contrast, the decision to choose nursing profession was mainly determined by the practical aspect such as the opportunity to find a job and motivation to the profession [9]. The current study supported having suffered from chronic diseases and stayed in the hospital to attend or care their relatives had positive influence in choosing the nursing profession. This may be true as they have observed and gained some experiences about the working environment as well as the work situation of the hospital and units, gaining positive insight into the nursing job.

\section{Academic Stress}

In this study, participants consistently rated high academic stress in most items. Course workload and preparation for the examination, assignment workload, theoretical level of course content, demand for expected writing standard, meeting academic program demand, academic writing requirement, lectures lasting more than one hour, and standard of achievement were cited highly stressful. This is consistent with the findings of Parven et al. and Brown et al. [19] that the most commonly observed stress among the nursing students were fear of failure, uncertainty about future, lack of confidence, discomfort, nervousness, sadness, depression, negative attitudes, poor satisfaction about performance. Brown et al. [19] contend that a high degree of stress could be due to a high demand course workload and program structure. This may be true in Bhutanese context too as the nursing curriculum is loaded with five modules a semester which consisted of theory classes, assignments, group works, practical signing outs, clinical posting, course test and semester examination.

Further, students are required to pass in all the modules to proceed to the next level, which may be challenging and stressful to fulfill all the requirements. A significant relationship was found between academic stress and ethnicity with participants coming from Ngalo background (western Region of Bhutan) and reported a higher mean score in total and academic stress. Western region of Bhutan is generally considered more advanced in development both economically and educationally compared to other regions. Students coming from these regions of Bhutan could be more aware of the value of academic excellence contributing to higher stress. However, this finding deserves further exploration. Consistent with the studies in the past elsewhere [20,24], younger participants significantly reported higher work-related stress. Perceived inadequate knowledge and skills for practice could have attributed to higher work-related stress. Some study revealed a gradual increase in the stress level as they become senior in the nursing training [12]. A higher academic stress was associated with participants coming from parents with some form of education and non-farming background.

Empirically, most educated parents in Bhutan today demand higher academic performance and excellence from their children, which could be a source of stress for the children. However, this is in contrast to the observation made by Aslan and Akturk [24] where the stress score of the nursing students decreased with the increase in their parental educational level. Compared to participants with an experience of admission to the hospital, those having no experience of admission to the hospital significantly experienced greater work-related stress. This is consistent with the finding of Hoeve, Castelein [29] that nursing students with past working experience in health care were motivated to choose nursing as the career. 


\section{Work-Related Stress}

During the study, nursing students confront various types of stressors such as academic performance, workload, personal problems, environment, and practical work-related stresses $[17,30]$. The current study showed work-related stress associated with death and dying, the uncertainty of the patient treatment, conflict in the workplace, and lack of professional knowledge and skills. This finding agreed with an Ethiopian study [18] that death, dying, and uncertainty regarding patient treatment and work overload contributed to high work-related stress. Aslan et al. [24] alleged while clinical practice is necessary for students to develop professional knowledge and skills it is an important source of anxiety and stress. Nursing students in Bhutan are required to work and practice in the clinical areas from the end of semester one until they graduate. During clinical placement, Bhutanese nursing students are required to fulfill a number of clinical procedures, and requirements in different clinical settings. Working under limited supervision, knowledge and skills may be a source of work stress.

Furthermore, nursing students in Bhutan confronts fierce competition to get admission into the nursing profession after graduation due to limited number of intakes for the job, which may be stressful. The consequences of stress have a negative academic outcome, reduction in cognitive ability, impaired coping and incompletion of studies, failure to identify and address the students' perceived source of stress can lead to role confusion, decreased effort and productivity upon graduation [19] which were unfortunately not assessed in this study. Brown et al. [19] and Pulido Martos et al. [17] recommended that study program need to consider evading work overload for the nursing students and the nursing educators and clinical facilitators to remain sensitive of these stressors, provide students with effective coping strategies to deal stress during the period of their training. Likewise, Bhutanese nursing education program structure and academic workload along clinical posting require revision to reduce stress among the nursing students in Bhutan.

\section{Conclusion}

Bhutanese nursing students perceive nursing profession as dignified, respectable and an important profession for patient care. It is a profession with an opportunity to serve humanity and earn merits and virtues directly. However, nursing students experience various academic and work-related stresses during their training period. Course workload, exam preparations, assignments, theoretical level of course contents and meeting academic standards and demand, dealing with death and dying, uncertainty of patient treatment outcome and lack of professional knowledge and skills were common cited stressors. Hence, nursing study program need to consider revisits to avoid academic and work-related stress. Furthermore, nurse educators must remain sensitive to stress and provide students with effective coping strategies to deal stress during their study period.

\section{Conflict of Interest}

Authors declare no conflict of interest.

\section{Acknowledgement}

The authors would like to thank FNPH management for funding and the nursing students of FNPH and RAHS for participating in this study.

\section{References}

1. Hind M, Norman I, Cooper S, Gill E, Hilton R, et al. (2003) Interprofessional perceptions of health care students. Journal of Interprofessional Care 17(1): 21-34

2. Horton K, V Tschudin, A Forget (2007) The value of nursing: a literature review. Nursing ethics 14(6): 716-740

3. Weis D, MJ Schank (2017) Development and Psychometric Evaluation of the Nurses Professional Values Scale-3. Journal of Nursing Measurement 25(3): 400-410

4. Lai HL, Lin YP, Chang HK, Chen CJ, Peng TC, et al. (2008) Is nursing profession my first choice? A follow up survey in pre-registeration student nurses. Nurse Education Today 28(6): 768-776.

5. Bang KS, Kang JH, Jun MH, Kim HS, Son HM (2011) Professional values in Korean undergraduate nursing students. Nurse Educ Today 31(1): 72 75 .

6. Zulu C (2015) A survey on perception of the image of the nursing profession in Zambia by nursing students. Unified Journal of Nursing and Midwifery 1(1): 1- 14.

7. Al Jarrah IAT (2013) Assosiate nursing student's perceptions toward nursing profession in Jordan. European Scientific Journal 9(6).

8. Patidar AB, Jasbir Kaur, Suresh K Sharma, Neeraj Sharma, Anurag Bhai Patidar (2011) Future nurses' perception towards profession and carrier plans: A cross sectional survey in state Punjab. Nursing and Midwifery Research Journal 7(4).

9. Marcinowicz L, Owlasiuk A, Slusarska B, Zarzycka D, Pawlikowska $\mathrm{T}$ (2016) Choice and perception of the nursing profession from the perspective of Polish nursing students: a focus group study. BMC medical education 16(1): 243.

10.Zhang M, M Petrini (2008) Factors influencing Chinese undergraduate nursing students' perceptions of the nursing profession. International Nursing Review 55(3): 274-280.

11. Başkale H, P Serçekuş (2015) Nursing as career choice: perceptions of Turkish nursing students. Contemporary nurse 51(1): 5-15.

12. Cestari VRF, Islene Victor Barbosa, Raquel Sampaio Florêncio, Vera Lúcia Mendes de Paula Pessoa, Thereza Maria Magalhães Moreira (2017) Stress in nursing students: study on sociodemographic and academic vulnerabilities. Acta Paulista de Enfermagem 30(2): 190-196.

13. Ingwu J, O Iroka, B Ohaeri (2016) The professional image of nursing as perceived by nurses working in tertiary hospitals Enugu, Southeast Nigeria. African Journal of Nursing and Midwifery ISSN 2198-4638 4(1): 595-602.

14. Milton CL (2018) Will Nursing Continue as the Most Trusted Profession? An Ethical Overview. Nursing science quarterly 31(1): 15-16.

15. Stone A (2019) Nurses Ranked 'Most Trusted Profession' in 2019. ONS Voice 295-309.

16. Olshansky E (2011) Nursing as the most trusted profession: Why this is important. Journal of Professional Nursing 27(4): 193-194.

17. Pulido Martos M, JM Augusto Landa, E Lopez Zafra (2012) Sources of stress in nursing students: a systematic review of quantitative studies. International Nursing Review 59(1): 15-25. 
18. Dagget T, A Molla, T Belachew (2016) Job related stress among nurses working in Jimma Zone public hospitals, South West Ethiopia: a cross sectional study. BMC nursing 16(5): 39.

19. Brown K, P Anderson Johnson, AN McPherson (2016) Academic-related stress among graduate students in nursing in a Jamaican school of nursing. Nurse education in practice 20: 117-124.

20. Aedh AI, NK Elfaki, IA Mohamed (2015) Factors associated with stress among nursing students (Najran University-Saudi Arabia). IOSR J Nursing Health Sci 4(6): 33-38.

21. He FX, Turnbull B, Kirshbaum MN, Phillips B, Klainin Yobas P (2018) Assessing stress, protective factors and psychological well-being among undergraduate nursing students. Nurse Education Today 68: 4-12.

22. Hamaideh SH, H Al Omari, H Al Modallal (2017) Nursing students perceived stress and coping behaviors in clinical training in Saudi Arabia. Journal of Mental Health 26(3): 197-203.

23. Graham MM, Lindo J, Bryan VD, Weaver S (2016) Factors Associated With Stress Among Second Year Student Nurses During Clinical Training in Jamaica. Journal of Professional Nursing 32(5): 383-391.

\section{ISSN: 2574-1241}

DOI: 10.26717/BJSTR.2019.22.003752

Ugyen Wangdi. Biomed J Sci \& Tech Res

This work is licensed under Creative Commons Attribution 4.0 License

Submission Link: https://biomedres.us/submit-manuscript.php
24. Aslan H, U Akturk (2018) Nursing education stress levels of nursing students and the associated factors Annals of Medical Research. 25(4): 660-666.

25. (2017) Ministry of Health, Annual Health Bulletin.

26. Cho E, S Kim (2015) Cronbach's coefficient alpha: Well known but poorly understood. Organizational Research Methods 18(2): 207-230.

27. Khesar Gyalpo (2018)University of Medical Sciences of Bhutan, Admission Criteria.

28. Swarna S (2015) Nursing Students Perception towards Profession and Future Intentions. IOSR Journal of Nursing and Health Science (IOSRJNHS) 4(5): 30-34.

29. Hoeve TY, Castelein S, Jansen W, Jansen G, Roodbol P (2016) Predicting factors of positive orientation and attitudes towards nursing: A quantitative cross-sectional study. Nurse education today 40: 111-117.

30. Parveen A, S Inayat (2017) Evaluation of factors of stress among Nursing Students. Advanced Practices in Nursing 2(2): 136.

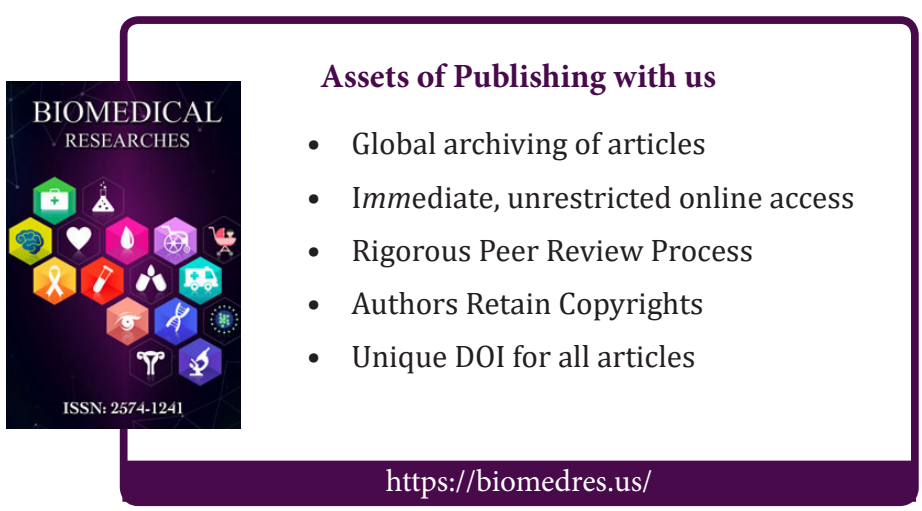

